See discussions, stats, and author profiles for this publication at: https://www.researchgate.net/publication/294726688

\title{
Determinants of knowledge management systems success in the banking
} industry

Article in VINE Journal of Information and Knowledge Management Systems · February 2016 DOI: 10.1108/VIIKMS-03-2014-0021

\section{CITATIONS}

20

1 author:

2. Tat Huei Cham

Universiti Tunku Abdul Rahman

41 PUBLICATIONS 528 CITATIONS

SEE PROFILE

Some of the authors of this publication are also working on these related projects:

Project Financial Technology (FinTech) View project

Project Hospitality and Tourism View project 
VJIKMS

46,1

2

Received 21 March 2014

Revised 6 November 2014

10 March 2015

28 May 2015

Accepted 5July 2015

\section{Determinants of knowledge management systems success in the banking industry}

\author{
Tat Huei Cham and Yet Mee Lim \\ Faculty of Accountancy and Management, \\ Universiti Tunku Abdul Rahman (UTAR), Selangor, Malaysia \\ Boon Liat Cheng \\ Department of Marketing, Sunway University, Selangor, Malaysia, and \\ Teck Heang Lee \\ Faculty of Business, Economics and Accounting, HELP University, Malaysia
}

\begin{abstract}
Purpose - This study aims to examine the impact from technical and social aspects on knowledge management system (KMS) success. Moreover, this study also attempts to examine the interrelationships between KMS success and user satisfaction.

Design/methodology/approach - A questionnaire survey was used to collect data from the commercial bank officers to test the proposed KMS success model. All the measurement scales adopted in this study were adopted from the existing literature. The data collected in this study were analysed using both SPSS and structural equation modelling approach via AMOS.

Findings - The research results indicate that both technical (knowledge quality, system quality and service quality) and social factors (user trust and management support) play a significant and positive role in system user satisfaction. The results also show that user satisfaction have a direct influence on the success of KMS and vice versa.

Originality/value - This study is one of the few studies on KMS which include both the technical and social perspectives in examining KMS success. This research study raises the importance of social factors, which have been earlier neglected by many studies on KMS success models. Moreover, the interrelationships relationship between KMS success and user satisfaction also been examined in this study.
\end{abstract}

Keywords Applied knowledge management, Knowledge management success factors, KM

Paper type Research paper

\section{Introduction}

In the highly competitive business world, the success of one's organization depends on how well the top management utilizes its corporate assets to achieve business goals. These assets can be categorized into tangible (e.g. financial capital, buildings and employees) and intangible form (e.g. knowledge, corporate image and branding). Conventionally, most of the firms have prioritized on the tangible aspects in their day-to-day operations. However, this trend seems to have taken a change where majority of the business entities have begun to emphasize on the intangible aspect especially the management of the organization's "knowledge" (Vorbeck et al., 2003). Knowledge itself has become a critical resource. It is an imperative element for
VINE Journal of Information and Knowledge Management System Vol. 46 No. 1, 2016

pp. 2-20

(C) Emerald Group Publishing Limite 2059-5891

DOI 10.1108/VJIKMS-03-2014-0021 
businesses to solve operational problems and to make decisions to support business strategies (McFayden and Canella, 2004). The importance of KMS is gradually recognized in line with the increasing need of firms to achieve sustainable competitive advantages (Turban et al., 2008). As a result, knowledge has been treated systematically much like other tangible resources, and many organizations are exploring the field of knowledge management (KM) to sustain their competitiveness.

In today's business environment, knowledge-based technologies such as microelectronics, computers, telecommunications, man-made gadgets and robotics have been deployed to cater for knowledge management initiatives by forming a system known as knowledge management system (KMS).KMS makes internal knowledge available to the employees and provides information for organizational learning (Damodaran and Olphert, 2000). Moreover, Galandere-Zile and Vinogradova (2005) explained that knowledge in the business context was considered a form of actionable information and KMS is a form of information system (IS). Hence, IS and KMS have often been used interchangeably by various authorities in the field (Halawi et al., 2007; Nattapol et al., 2010; Tsai and Chen, 2007; Wilson, 2002). Thus, the concepts and discussion of IS are equally applicable to KMS.

Since the inception of KMS, many firms have engaged actively in KMS to obtain benefits from the use of the system. The use of KMS is especially needed in financial institutes such as banks, which rely heavily on information (knowledge) to develop their products and services. The effective use and management of knowledge has been recognized as the most significant aspect for understanding the market conditions, investment strategies, customers' requirements and their expectations. Knowledge has been seen as the determinant of quality service performance especially when banking products are virtually perceived as identical to one another (Silver and Berggren, 2010). Although knowledge management-related issues have received fairly extensive attention in previous research (Akhvan, 2008; Halawi et al., 2007; Wasko and Faraj, 2005) and huge resources have been invested in developing and introducing KMS to employees, little effort has been given on finding out what factors contribute to the success of KMS. These factors could be significant indicators for banks and any other high-calibre industries to adopt KMS in their business operations.

With regards to the models on the success of KMS, the past studies have looked into the success in relation to users' satisfaction and their intention to use the system (DeLone and McLean, 2004; Halawi et al., 2007; Kulkarni et al., 2007). However, these models may not be applicable to the banking industry. According to Lucas (1978) and DeLone and McLean $(1992,2002)$, the intention to use should only be considered as a predictor of KMS success when the adoption of the system is on a voluntary basis. When KMS users are made compulsory to utilize the system as part of their job requirements, user's intention to use KMS is no longer appropriate in addressing the success of KMS. In the banking industry, most of the bank employees are not given a choice by their employers whether to use or not to use KMS. The bank employees have to use the system, as it is an essential tool for them to execute their jobs and to fulfill their job descriptions. Therefore, the intention to use the system as an antecedent for the success of KMS seems to be inappropriate in this case.

In addition, previous research studies have emphasized on the technical aspects of the system in examining their success (Agourram and Ingham, 2007; DeLone and McLean, 2003; Jennex and Olfman, 2003; Halawi et al., 2007; Nattapol et al., 2010). The 
VJIKMS

46,1

three technical aspects commonly studied are knowledge quality, system quality and service quality. Studies on KMS that consider the impact from the social aspects such as user trust and management support in relation to the success of KMS are still scarce and have little empirical evidence (Tsai and Chen, 2007). The social aspects of trust and support are part of the organizational culture to facilitate the utilization and implementation of knowledge (Inkpen, 1996). Trust is needed to operate a knowledge-based system effectively and a trusting culture may enhance the exchange of knowledge (Roberts, 2000). Therefore, the inclusion of social aspects is vital in predicting the success of KMS.

The objective for this study is to understand the importance of both technical and social factors that can lead to the success of KMS implementation via users' satisfaction with the system in the context of Malaysian banking industry. The technical aspects considered in this study were adopted from the Delone and McLean's IS success model (2002), namely, knowledge quality, system quality and service quality. The social aspects are trust with the system and management support. The present study attempts to deal with the scarcity of previous research with respect to the social aspects of KMS, specifically in the Malaysian banking industry. This empirically integrated model developed for this study will be useful to researchers in further developing and testing KMS success model for the industry where KMS is a must to the employees. This paper includes a literature review on KMS and its success models, a methodology section and a discussion section on the implications of the research findings.

\section{Literature review}

\subsection{Knowledge management systems}

In view of the importance of knowledge in creating sustainable competitive edge, many business organizations have adopted a systematic approach in managing organizational knowledge. Although the concept of KM has been defined in different ways, KM principally refers to how organizations create, retain and share the organizational knowledge that they have possessed (Huber 1991). The value of knowledge would upsurge when it is shared effectively among the users (Cabrera and Cabrera, 2002). Wiig et al. (1997) pointed out that KM in business organizations does not carry its name accidentally because the term management itself usually signifies "something" has to be managed. And this process of managing knowledge enables the organization to deal with changes and to interact with the external environment effectively (Alavi and Leidner, 2001).

To facilitate the process, information and communication technology tools have been deployed to form an inclusive system of managing organizational knowledge known as KMS. This KMS is an IT-based system developed to support the organizational KM behaviour and to deliver the best outcomes for knowledge diffusion, learning enhancement, product and service innovation and environmental responsiveness (Agourram and Ingham, 2007; Alavi and Leidner, 2001; Jennex and Olfman, 2003; Tseng, 2008). Thus, KMS serves as the platform for sharing crucial information, decision-making, strategy crafting and increased intellectual capability of the organization.

The advantages of KMS as part of organizational practice have been observed in various multinational companies such as Texas Instrument, Chevron and Ford. These companies have successfully saved millions of dollars via the usage of KMS in their 
day-to-day operations (Bose, 2004). Although it has been reported that some of the KMS efforts fall short in delivering the expected benefits for the practitioner (Hickins, 1999; KPMG, 2000), KMS is still considered an important business tool. Furthermore, the number of adoption of KMS in business operations is still increasing till today (Agourram and Ingham, 2007; Tsai and Chen, 2007). The above scenario reveals that KMS has become an organizational trend nowadays due to the benefits of the system. Chua et al. (2007) contended that companies gain competitive advantage not only directly from the amount of knowledge they gather but also from the capability of KMS to perform at its utmost capacity and to stay relevant to the users' needs. However, as organizations continue to operate in a dynamic environment where changes are constant and rapid, examining the factors in relation to the success of KMS becomes critical to ensure its contributions to the success of the organization (Halawi et al., 2007).

\subsection{Knowledge management success models}

As seen from the literature, the models used to examine the success of KMS have been developed based on DeLone and McLean's IS Success Model (Agourram and Ingham, 2007; Jennex and Olfman, 2003; Halawi et al., 2007; Nattapol et al., 2010). According to DeLone and McLean (2003), the IS success model consists of six interrelated constructs: service quality, information quality, system quality, user satisfaction, use and net benefits. This model has then been adopted by Jennex and Olfman (2003) in their study of KMS success. Since then, the KMS success model was further evolved by Halawi et al. (2007) when they conducted an empirical study to address the success of KMS. The KMS success model developed by Halawi et al. (2007) consisted of five constructs, namely, knowledge quality, system quality, service quality, intention to use, user satisfaction and knowledge management success. So far the social factors have been largely left out in these models. Thus, Nattapol et al. (2010) included the trust factor in their study of the success of KMS. But the inclusion of management support as the other social aspect in the KMS success model is still limited. The present research study, therefore, has included management support in the research model in examining the success of KMS in the banking industry. In addition, the present research model excludes users' intention to use, as this factor deems to be inappropriate in the context of banking industry where the use of KMS is compulsory. The research model developed for this study is shown in the next section along with the research hypotheses.

\subsection{Hypotheses development and research model}

The following sections present the literature on the relationships between the technical aspects (knowledge quality, system quality and service quality), social aspects (user trust and management support), user satisfaction and KMS success, as well as their respective hypotheses. The hypotheses developed for this study were also shown graphically in the research model at the end of the section.

2.3.1 Technical aspects

2.3.1.1 Knowledge quality. For the purpose of this study, knowledge quality is defined as the extent to which knowledge object successfully serves the purposes of users (Kahn et al., 2002). According to Kahn et al. (2002), it is reported that knowledge quality has become a critical issue in creating competitive advantage and in dealing with the rapidly changing business environments. When quality knowledge is up-to-date, reliable, accurate and easily used, it is capable to facilitate decision-making process in the 
VJIKMS

46,1 business platforms (DeLone and McLean, 2003). Moreover, knowledge quality has been suggested in the previous literature as an antecedent and integral part of the user's satisfaction (DeLone and McLean, 2003; Jennex and Olfman, 2003; Kulkarni et al., 2007). The quality of content contribution is essential for KMS's success. It ultimately enables the users to perceive the KMS to be more beneficial and to experience a higher level of satisfaction (Jennex and Olfman, 2003). Halawi (2005) claimed that the richness of knowledge quality is essential to encourage knowledge sharing among the users and directly enhance the knowledge utilization among the users in an organization. When users expect to receive more benefits such as quality knowledge from KMS, they are more likely to satisfy with it (Jennex and Olfman, 2003; Halawi et al., 2007). These arguments imply that quality knowledge plays an important role in determining user satisfaction (Nattapol et al., 2010). Therefore, it was hypothesized that:

H1. Knowledge quality has a positive influence on user satisfaction with knowledge management system.

2.3.1.2 System quality. In accordance with Wu and Wang (2006), system quality is defined as how well the KMS performs in the context of its operational aspects. The importance of system quality in the aspect of KMS has facilitated all the processes that have taken place in the system. As for knowledge sharing and codification in KMS, it is important to have a system structure that enables faster and easier codification of knowledge (Alavi and Leidner, 2001; Davenport and Prusak, 1998). Advanced storage and retrieval tools can effectively enhance organizational memory and repository of KMS (Alavi and Leidner, 2001). Moreover, Goodman and Darr (1998) claimed that the ease of storage and retrieval of knowledge could encourage people to contribute knowledge into the system. Likewise, Al-Busaidi et al. (2010) found that system quality in terms of ease of use, speed and integrated functions is critical for knowledge sharing behaviour. The benefits of knowledge sharing have been seen to play an important role in helping business to make speed decisions and to respond optimally to the market changes. A system that is perceived to be easy to use may also be perceived to be high in quality. Wu and Wang (2006) mentioned that KMS with a high system quality would help reduce users' "negative mood" such as impatience while using the system. Therefore, system quality provides the means to effective facilitation of knowledge respiratory in KMS and has a significant influence on users' satisfaction (Wu and Wang, 2006). In addition, studies that found a positive relationship between high system quality and users' satisfaction include Jennex and Olfman (2003), Halawi et al. (2007) and Nattapol et al. (2010). Therefore, the following hypothesis was formulated:

H2. System quality has a positive influence on user satisfaction with knowledge management system.

2.3.1.3 Service quality. Service quality refers to the fulfilment of delivered service in meeting customers' requirements, expectations and satisfactions (Parasuraman et al., 1985). In the context of KMS, service quality means how well the subject-matter experts and KMS managers support the KMS activities (Jennex and Olfman, 2005; Al-Busaidi et al., 2010). This support consists of providing guidance and training to the users on how to query and use knowledge and making knowledge capture and reuse as part of the business process routines. Delone and McLean (2003) have also proposed that service quality has to be included in KMS success conceptual framework to 
acknowledge its significance. Moreover, service quality has been found to be the most significant variable in contributing to users satisfaction with the system and the overall success of the KMS initiative (Al-Busaidi et al., 2010; Delone and McLean, 2004; Halawi et al., 2007; Kettinger and Lee, 2005; Nattapol et al., 2010; Tsai and Chen, 2007). In addition, Brady et al. (2002) found that service quality was an important factor in creating good attitude and user satisfaction in their study of information technology. In sum, various past studies have found a positive relationship between service quality and the level of user satisfaction. It was then hypothesized that:

H3. Service quality has a positive influence on user satisfaction with knowledge management system.

\subsubsection{Social aspects}

2.3.2.1 User trust. According to Thatcher et al. (2007), trust in the context of information technology refers to trusting beliefs for a particular system. It was documented that that lacking of trust in the usage for a particular system may cause users to believed that the system they used have limitation in terms of predictability or functionality which may lead them to stop it (Thatcher et al., 2007). As for KMS, trust in KMS is synonymous to trust in IS where reliable, dependable and quality system performance are the key indicators for confidence building (Malhotra, 2004). User trust in KMS has been viewed as a key factor that enhances effective knowledge exchanges and provides a context for cooperation (Adler, 2001; Tsai and Ghoshal 1998). Levin and Cross (2004) have found that user trust predicts the perceived usefulness an individual feels about the system. It has also been found that KMS users will feel more certain and comfortable to use the system in performing their jobs when they trust the functionality of the KMS (He et al., 2009). This means that when KMS users trust the system to do them good, they are more likely to think that the system is useful and beneficial to them. In view of that, trust was considered a determinant of user satisfaction (Al-Busaidi et al., 2010; Nattapol et al., 2010). Trust must exist between the users and the system so that the latter can be used to achieve the desired purpose and eventually satisfaction among the users. Based on the past literature, the following hypothesis was postulated:

H4. User trust has a positive influence on user satisfaction with knowledge management system.

2.3.2.2 Management support. Management support in this study refers to the activities performed by the higher management in clarifying the goal and vision of KMS to the users and in encouraging them to get involved with the system directly (Gold et al., 2001). A number of research studies have discussed the importance of management support or leadership in KM initiatives (Massey et al., 2002; Pan et al., 2001). Venkatesh and Bala (2008) argued that when users hold a strong belief regarding the availability of organization resources, technical and managerial support, they will undoubtedly adopt that technology. Moreover, there are many researchers in the IS context who agreed that the support from top management play an important role in determining the success of IS implementation (Masrek et al., 2007). Top management support was reported to have a significant impact on the success of executive ISs by creating a supportive environment for the parties involved directly with the system (Ragu-Nathan et al., 2004). Furthermore, past research studies have also shown a significant correlation between management support and user satisfaction on a particular system or technology
Knowledge management systems success 
VJIKMS

46,1

2.3.3 The relationships between user satisfaction and knowledge management system success. For this study, user satisfaction with KMS refers to an overall evaluation of KMS (McGill et al., 2003), whereas KMS success is referred to as the valuation of the benefits of the KMS by the users (Halawi et al., 2007). Previous research studies had found that the user satisfaction on KMS will directly influence the success rate of KMS (Alavi and Leidner, 2001; Jennex, 2005). In other words, those users who satisfied with the KMS that they used, they will recognized the success of KMS in terms of overall benefits delivered. The benefits that are associated with the success of KMS include efficiency in managing and storing knowledge, helping users in acquiring new knowledge, the ability to accomplish users' tasks, improving decision-making process and improvement in users' quality of working life (Halawi et al., 2007; Jennex, 2005). Other studies which have recognized a positive relationship between user satisfaction and KM success include Halawi et al. (2007), Kwahk and Oh (2009) and Ragab and Arisha (2013). Hence, it can be inferred that user satisfaction is associated with the success of KMS.

However, previous studies have also found a reverse relationship whereby the success of KMS could determine the satisfaction level of the users (Alavi and Leidner, 2001; Jennex, 2005). In other words, the users who recognize the benefits delivered by KMS will be satisfied with the system as a whole (Wu and Wang, 2006). Based on the two-way relationship between user satisfaction and success of KMS, two hypotheses were developed as follows:

H6. User satisfaction has a positive impact on the success of KMS.

H7. The success of KMS has a positive impact on user satisfaction.

Figure 1 below shows the research model of this study.

Figure 1.

Research model

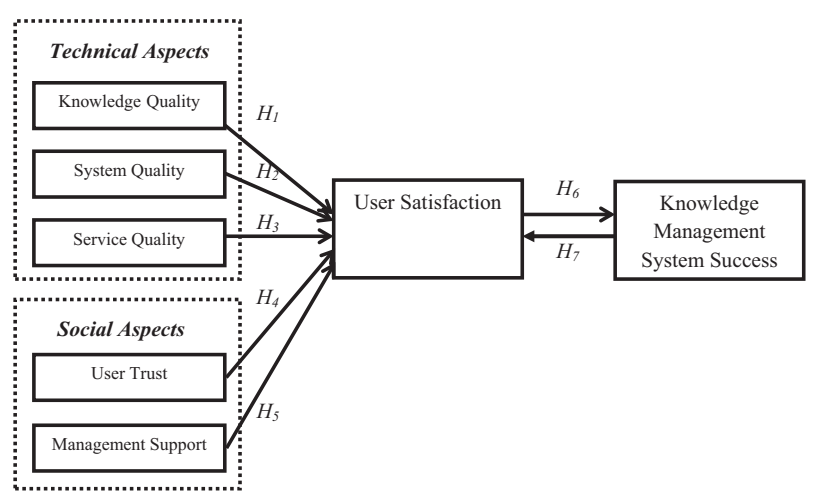




\section{Methodology}

\subsection{Sampling method}

The target respondents of this study were the bank employees situated in the Klang Valley region of Malaysia with a high density of commercial banks. A quota sampling was used to collect data to empirically test the proposed research model in this study. To ensure reliable and justifiable responses, the researchers have imposed two screening criteria before the questionnaires were distributed to the respondents. The two screening criteria were:

(1) the respondents must have had worked for at least six months with the bank; and

(2) their jobs must have involved with any KMS (e.g. company intranet, company database, Malaysia Central Credit Reference Information System and Malaysia Dishonoured Cheque Information System).

The respondents who fulfilled these two requirements were then qualified as the target respondents in this study. A total of 250 questionnaires were distributed evenly to the target respondents from five commercial banks. A total of 217 questionnaires were received with a response rate of 87 per cent. However, 13 of them were discarded due to incompleteness, yielding a sample size of 204. A sample size of 204 was considered adequate for data analysis for the purpose of this study. Based on the approach by Hair et al. (2006), the appropriate sample size for the study can be determined based on the statistical formula of multiplying the number of measurement items in the questionnaire by five. As the measurement scales used in this research have 34 items in total, the sample size should therefore be 170 and above. Furthermore, prior studies also consistently reported that a "critical sample size" of above 200 is adequate to provide sufficient statistical power for data analysis (Comrey and Lee, 1992; Hair et al., 2006; Schmidt and Hollensen, 2006). Hence, the sample size of 204 obtained from this study is considered large enough for data analysis.

\subsection{Measurement}

All items used to measure the variables in this study were based on the existing measurement scales in the KMS literature and the inputs of KMS experts. All of the items were measured based on a seven-point Likert scale ranging from (1) "strongly disagree" to (7) "strongly agree". The items used to measured knowledge quality were adapted from DeLone and McLean's (2003) study; which covers relevance, timeliness and completeness of information/knowledge provided by the KMS. The system quality scale in this study was adapted from Wu and Wang (2006) and was operationalized by four items:

(1) acceptable response time;

(2) system stability;

(3) ease of use; and

(4) a user-friendly interface.

Based on the study by Nattapol et al. (2010), service quality was measured using five items in the areas of adequate support, response rate, understanding user specific need,
Knowledge management systems success 
VJIKMS

46,1

having sufficient knowledge to users' need and imposing empathy when users have problems with the system.

Similarly, user trust was measured using four items adapted from the trust scale by Nattapol et al. (2010). The measurement items for user trust include confidence in the system's knowledge, beliefs in the system, and truth and reliable knowledge for the system. Management support for this study was adopted from the study by Al-Busaidi et al. (2010) and was measured using four items that relates to the role of senior management in assisting KMS users with supports, ensuring the objectives of the KMS are achieved, encouraging knowledge exchange and emphasis on the importance of KMS. User satisfaction refers to the sum of one's feelings of pleasure or displeasure regarding the use of KMS, and was measured by four items adapted from a satisfaction scale developed by Wu and Wang (2006). KMSs success is about the valuation of the benefits of the KMS by the users and was measured with five-item KMS success scale developed by Halawi et al. (2007). The scale consists of the benefits of KMS in helping users to new knowledge acquisition, managing knowledge, decision-making, improve quality of work life and task accomplishment.

A pilot test was carried out before the actual data collection to ascertain the reliability of the survey instruments and to test for the clarity of items. The pretest of the questionnaire was conducted using five IS experts and a group of ten finance officers. They were asked to provide comments on the questionnaire content and structure to assess item adequacy, question relevancy and wording clarity. The pretest respondents indicated that the questions of the survey were adequate in terms of construct coverage and relevant. Hence, the face validity of the scales was established.

\section{Data analysis and result}

Data collected were statistically analysed using SEM according to the objectives of the research. First, descriptive statistics were used to describe respondents' demographic (Table I). Second, data were checked for its reliability and validity. Third, the fit of the research model was conducted with the use of analysis of moment structures (AMOS). Finally, the results of hypotheses were presented.

\subsection{Sample characteristics}

As shown in Table I, the respondents consisted of 58.33 per cent female and 41.67 per cent male bank employees. Almost all of them were local Malaysians ( 96.00 per cent) and two-third of them possessed 1-6 years of experience in using KMS. Majority of the respondents owned a bachelor degree (60 per cent) and two-third of them used KMS one to six hours per day in performing their jobs.

\subsection{Convergent and discriminant validity of the constructs}

Confirmatory factor analysis (CFA) is used to test the validity and reliability of the constructs by examining the fit of the measurement model. Examining the model fit involves testing whether the observed variables are significantly related to their respective latent variables. The relationships between the observed and latent variables are postulated based on the existing measurement scales adopted from the literature. According to Hair et al. (2006), the criteria used in the evaluation of model fit included the justification of absolute fit measures, incremental fit measures and parsimonious fit indices - Comparative fit index (CFI), root mean square error of approximation (RMSEA), goodness of fit (GFI), Tucker-Lewis index (TLI), normed 


\begin{tabular}{|c|c|c|c|}
\hline Variables & Classifications & $(\%)$ & Knowledge \\
\hline \multirow[t]{2}{*}{ Gender } & Male & 41.5 & systems \\
\hline & Female & 58.5 & \\
\hline \multirow[t]{2}{*}{ Nationality } & Malaysian & 96.0 & success \\
\hline & Non-Malaysian & 4.0 & \\
\hline \multirow[t]{5}{*}{ Education level } & Certificate/Diploma & 24.50 & 11 \\
\hline & Degree & 60.0 & \\
\hline & Master & 13.0 & \\
\hline & Doctoral & 0.5 & \\
\hline & Professional certificate & 2 & \\
\hline \multirow[t]{4}{*}{ Years of experience with KMS } & $1-3$ years & 33.5 & \\
\hline & 4-6 years & 35.5 & \\
\hline & 7-9 years & 19.5 & \\
\hline & 10 years and above & 11.5 & \\
\hline \multirow[t]{4}{*}{ Average hours of using KMS per day } & $1-3$ hours & 37.5 & \\
\hline & 4-6 hours & 33.5 & \\
\hline & $7-9$ hours & 23.5 & \\
\hline & 10 hours and above & 5.5 & $\begin{array}{l}\text { Table I. } \\
\text { Sample }\end{array}$ \\
\hline Note: $n=204$ & & & characteristics \\
\hline
\end{tabular}

chi-square $\left(\chi^{2} / \mathrm{df}\right)$ and parsimony normed fit index (PNFI). For a model with a good fit, CFI should exceed 0.90, RMSEA should be less than 0.08, GFI and TLI should exceed $0.80, \chi^{2} /$ df should be less than 3.0 and PNFI should be less than 0.50 (Hair et al., 2006). Table II shows the results of the convergent and discriminant validity tests. Based on the data collected in this study, the results of the CFA indicated that the model was fit with the value of GFI was 0.898 , RMSEA was 0.053 , TLI was 0.913 , CFI was 0.923 , Normed chi-square $\left(\chi^{2} / \mathrm{df}\right)$ was $1.580\left(\chi^{2}=644.771\right.$; $\left.\mathrm{df}=408\right)$ and PNFI was 0.718.

To assess convergent validity, each item of the latent constructs should have an estimate factor loading of at least 0.60 , the average variance extracted should be

\begin{tabular}{lccccccccccc}
\hline Variables & ITEMS & CR & AVE & FL & UT & SVQ & KQ & KMSS & SQ & US & MS \\
\hline UT & 4 & 0.956 & 0.844 & $0.88-0.95$ & $\mathbf{0 . 9 1 8}$ & & & & & & \\
SVQ & 5 & 0.848 & 0.530 & $0.61-0.86$ & 0.005 & $\mathbf{0 . 7 2 8}$ & & & & & \\
KQ & 5 & 0.874 & 0.581 & $0.71-0.83$ & 0.117 & 0.397 & $\mathbf{0 . 7 6 2}$ & & & & \\
KMSS & 5 & 0.920 & 0.696 & $0.80-0.87$ & 0.169 & 0.147 & 0.201 & $\mathbf{0 . 8 3 5}$ & & & \\
SQ & 5 & 0.835 & 0.562 & $0.67-0.85$ & 0.006 & 0.196 & 0.005 & 0.125 & $\mathbf{0 . 7 4 9}$ & & \\
US & 4 & 0.884 & 0.656 & $0.77-0.86$ & 0.264 & 0.502 & 0.636 & 0.445 & 0.212 & $\mathbf{0 . 8 1 0}$ & \\
MS & 4 & 0.829 & 0.549 & $0.71-0.81$ & 0.133 & 0.382 & 0.218 & 0.007 & 0.173 & 0.460 & $\mathbf{0 . 7 4 1}$
\end{tabular}

Notes: $\mathrm{CR}=$ Composite reliability; $\mathrm{AVE}=$ average variance extracted; $\mathrm{FL}=$ factor loading; $\mathrm{UT}=$ user trust; $\mathrm{SVQ}=$ service quality; $\mathrm{KQ}=$ knowledge quality; KMSS = knowledge management system success; $\mathrm{SQ}=$ system quality; US = user satisfaction; $\mathrm{MS}$ = management support; the diagonal entries (in bold) represent the squared root average variance extracted by the construct; the off-diagonal entries (in italics) represent the variance shared between constructs

Table II.

Test results of convergent validity and discriminant validity 
VJIKMS

46,1

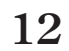

larger than 0.50 and composite reliability should be greater than 0.70 (Hair et al., 2006). Moreover, the factor loadings of all the construct items were ranged from 0.60 to 0.87 ; thus, none of the items of the constructs were removed. Besides, the average variance extracted of each construct exceeds the cut-off point of 0.50 , and each construct has a composite reliability of more than 0.70. Likewise, the Cronbach's alpha value for each construct showed in the table was well above the recommended value of 0.70 , which is considered satisfactory for basic research (Hair et al. 2006). These reliability coefficients indicate that all measures in the study have achieved a good internal reliability.

In addition, discriminant validity of the measurement scales was assessed using the guideline suggested by Fornell and Larcker (1981) where the squared root of average variance extracted for each of the constructs should exceed the variance shared between any other constructs. As shown in Table II, the squared root of average variance extracted in the diagonal entries all exceed the shared variance between constructs (the off diagonal entries); hence, the discriminant validity of the measures was established. In sum, all constructs for this study used in this study have demonstrated adequate convergent validity, discriminant validity and reliability.

\subsection{Structural model testing and hypotheses testing}

Structural equation modelling (SEM) was used to examine the overall fit of the model and the relative strengths of the individual causal paths. The results of the model fit are shown in Table III. For the current research model, the GFI was 0.832, RMSEA was 0.057, TLI was 0.923, CFI was 0.931, Normed chi-square ( $\left.\chi^{2} / \mathrm{df}\right)$ was $1.657\left(\chi^{2}=690.956\right.$; $\mathrm{df}=417)$ and PNFI was 0.756. All the indices shown in the Table III suggest an acceptable model fit. Given an adequate measurement model, the hypotheses can be tested by examining the proposed structural model. Table IV shows that all the hypotheses developed for this study were supported. The standardized path coefficients for hypotheses $H 1$ and $H 5$ were significant at 99 per cent confidence level, whereas those of $\mathrm{H} 2, \mathrm{H3}, \mathrm{H4}, \mathrm{H} 6$ and $\mathrm{H} 7$ were significant at 95 per cent confidence level. The results show that all the proposed relations in this study are supported. The tests of the structural model showed that all the hypothesized antecedents (knowledge quality, system quality, service quality, management support and user trust) have a positive relationship with user satisfaction with KMS, which in turn relates positively to the success of the system. Likewise, the results also showed that KMS success also positively influences user satisfaction.

\begin{tabular}{llr}
\hline Fit index & Recommended cut-off value & Scores \\
\hline Goodness of fit (GFI) & $>0.80$ (MacCallum and Hong, 1997) & 0.832 \\
Root mean square error of approximation & & \\
(RMSEA) & $>0.08$ (Ferdinand, 2006) & 0.057 \\
Tucker-Lewis index (TLI) & $>0.80$ (Razak and Abduh, 2012) & 0.923 \\
Comparative fit index (CFI) & $>0.90$ (Hair et al., 2006) & 0.931 \\
Normed chi-square $\left(\chi^{2} / \mathrm{df}\right)$ & $>0$ (Hair et al., 2006) & 1.657 \\
Parsimony normed fit index (PNFI) & & 0.756 \\
Chi-square $\left(\chi^{2}\right)$ & & 690.956 \\
Degree of feedom (df) & & 417 \\
\hline
\end{tabular}

Table III.

Overall fit indices of the structural model and its cut-off value

Degree of feedom (df) 


\section{Discussion and conclusion}

There are several findings in this study are worth noting. First of all, knowledge quality is shown to be significantly associated with user satisfaction. This finding revealed that the quality of knowledge in the banks' KMS has a positive direct influence on the users' satisfaction. Specifically, this means that the quality in knowledge will provide valid and more reliable sources of information for the users of KMS in this study, thus resulting in their usage satisfaction. Moreover, the result of analysis in this study is consistent with evidence from the previous studies (DeLone and McLean, 2003; Jennex and Olfman, 2003; Kulkarni et al., 2007). Therefore, there is a need for the management team of the banks to implement strategies such as knowledge refinement and formal review processes to ensure that the quality of knowledge in their KMS is reliable and useful to their staff.

Second, this study found that quality of the system for the banks' KMS has also positively influence users' satisfaction. This evidence demonstrates that inferior quality for the KMS in the context of outdated technologies, complicated user interface, unreliable functions, etc. will definitely affect the users' satisfaction with the system. Moreover, the findings from this study dovetails with the prior research studies where it can be conceded that system quality seems as a positive contributor to users' satisfaction (Jennex and Olfman, 2003; Halawi et al., 2007; Nattapol et al., 2010). In view of that, therefore, there is a need for banks to emphasize on the improvement of system quality for their KMS by centralizing their database, system integration, latest computers, fast broadband and faster business servers would help reduce errors and improve productivity among the users, which in turn would lead to their satisfaction with the system. This is because reliable system quality has a high impact on the KMS processes in terms of ease of use, response rates,and the accuracy of the codified business information in which will contribute positively to the business performance (King and Marks, 2008).

Third, service quality for the banks' KMS was found to have a significant positive influence on user satisfaction. This significant relationship shows that service quality is an important aspect, as it is what the end users (banks employees) experience with the system. This scenario orchestrated that the end users are like customers and they need a system which would provide adequate technical support and fast response rate in solving problems. It is argued that system which is able to fulfil the users' needs would promote satisfaction among them (Kettinger and Lee, 2005). Moreover, the relationship

\begin{tabular}{lccl}
\hline Hypothesized path & $\begin{array}{c}\text { Standard } \\
\text { estimate }\end{array}$ & $\begin{array}{c}\text { Critical } \\
\text { ratio }\end{array}$ & $\begin{array}{c}\text { Hypothesis } \\
\text { supported }\end{array}$ \\
\hline H1. Knowledge quality $\rightarrow$ user satisfaction & 0.374 & $6.777^{* * *}$ & Yes \\
H2. System quality $\rightarrow$ user satisfaction & 0.142 & $2.015^{* *}$ & Yes \\
H3. Service quality $\rightarrow$ user satisfaction & 0.182 & $2.615^{* *}$ & Yes \\
H4. User trust $\rightarrow$ user satisfaction & 0.112 & $2.868^{* *}$ & Yes \\
H5. Management support $\rightarrow$ user satisfaction & 0.244 & $3.741^{* * *}$ & Yes \\
H6. User satisfaction $\rightarrow$ KMSS & 0.317 & $3.143^{* *}$ & Yes \\
H7. KMSS $\rightarrow$ user satisfaction & 0.162 & $2.472^{* *}$ & Yes
\end{tabular}

Notes: $* * * p$-value $<0.001 ; * * p$-value $<0.05 ; \mathrm{KMSS}=$ knowledge management system success
Knowledge management systems success

13 

study pertaining to KMS (Al-Busaidi et al., 2010; Delone and McLean, 2004; Halawi et al., 2007; Nattapol et al., 2010). Based on the importance of service quality for the KMS, it is recommended that the banks need to allocate sufficient resources in forming support team to assist and provide technical supports for the bank employees. By doing so, this will definitely promote the usage of the KMS among the employees in which will allow them to perform better in their works. Moreover, inclusion of "Help" and "Frequently Asked Questions" sections in the systems would also be considered helpful for the employees as a whole.

In addition, the social aspects for this study also share the similar results as the technical aspects where the results above reveal that both users' trusts and management supports have a significant positive influence on users' satisfaction for the banks' KMS in the banking industry. Specifically, it is reveal that the levels of trust among the employees on the banks' KMS have a positive direct influence on their usage satisfaction. This scenario evidently revealed that if the users trust the KMS, this will encourage them to use the KMS which in turn will directly make them satisfied with the system. Similar to this course, it was also reported that the level of trust from the users on the KMS is found to be necessary for KMS implementation and can facilitate the process of utilization of knowledge (Chua and Lam, 2005). This finding therefore reflects the importance of user trusts on the KMS in the banking industry. Referring to this fact, it is important for the management team to create an effective operation of knowledge base to create trust among employees on the system which may enhance their level of satisfaction (Nattapol et al., 2010). With that, knowledge managers will need to put extra effort in influencing or creating perception of trust among the users, as trust is based on individual perception. For example, managers can create user trust for the KMS by emphasizing on reliable and trustworthy aspects in the KMS architecture.

For the context of management support, the finding from this study affirmed that the support given by the banks' management team has shown a positive impact on user satisfaction for the KMS they used. This means that management support would facilitate the utilization of KMS among the banks' employees and able to upsurge the level of satisfaction among users of the system. Moreover, management support in the KMS context is argued to be important because it can create positive experiences and attitude among the users towards the system as a whole (Al-Busaidi and Olfman, 2005; Kulkarni et al., 2007). With that, therefore, there is a need for the management team to provide adequate support both in the context of financial and non-financial supports such as giving advice and guidance, emotional support, promoting strong teamwork and implementing incentives. As for example, the banks' management team is recommended to listen and attend to the user's feedbacks in the consistently to show that they care and valued the inputs from their employees. This approach is also vital, as it can allow the management team in crafting operational strategies and at the same time improving the current KMS to encourage users to use the system which will further drive their level of satisfaction.

On top of that, the findings from this research also indicated that user satisfaction has an influence on the success of KMS and vice versa, as hypothesized by DeLone and McLean (2003) in their study. This evidence support the fact that satisfied users will believed that the KMS they used is successful in terms of its existence (beneficial) for them in performing their job tasks. Besides, the result also revealed 
that benefits generated from KMS in the banking sector also have a direct influence on users' satisfaction. Other prior studies found a similar result include Jennex and Olfman (2003), McGill et al. (2003), Jennex (2005), Halawi et al. (2007) and Nattapol et al. (2010). The significant interrelationships imply that user satisfaction is a fundamental factor to which a KM manager should pay attention. Users' satisfaction would enhance their perceptions on the benefits of the system. Conversely, it can be argued that users' satisfaction could be enhanced by focusing on the benefits that a KMS bring to the end users too. A highly beneficial and effective KMS which is able to meet the needs and requirements of the users would improve their perceptions on the use of the system. Therefore, it is crucial for the organization to implement an effective KMS which facilitates users' job tasks and productivity, which would also significantly determine their satisfaction level.

Nevertheless, a notable limitation of this study is the research setting. This research is limited to the commercial banking industry only in Malaysia. It raises the issue of generalization and the findings of the present study might not be applicable to other industries which operate in different environments. Future studies should include other industries where KMS is an essential element in the business operations. Moreover, future research may examine the specific types of KMS and their respective associated success factors.

As the conclusion, there is no doubt that developing a reliable KMS has been a great advantage to enhance users satisfaction and at the same time to sustain competitive advantage for any organizations that adopted the system. Therefore, the process of building and maintaining a successful KMS has become a critical part of the organization strategically. Although the technical aspects play a crucial role in explaining user satisfaction and the success of the system, the social aspect cannot be largely ignored especially both of the factors have a significant impact on the success of the system as a whole. With that, both hard and soft sides of the system must be considered in implementing a KMS in the organization and also in the research context.

\section{References}

Adler, P.S. (2001), "Market, hierarchy, and trust: the knowledge economy and the future of capitalism", Organization Science, Vol. 22 No. 2, pp. 215-234.

Agourram, H. and Ingham, J. (2007), "The impact of national culture on the meaning of information system success at the user level", Iournal of Enterprise Information Management, Vol. 20 No. 6, pp. 641-656.

Akhvan (2008), “Ckm: were knowledge and customer meet”, Km Review, Vol. 11 No. 2, pp. 112-116.

Al-Busaidi, A.K. and Olfman, L. (2005), "An investigation of the determinants of knowledge management systems success in Omani organizations", Iournal of Global Information Technology Management, Vol. 8 No. 3, pp. 6-27.

Al Busaidi, K.A., Olfman, L., Ryan, T. and Leroy, G. (2010), "Sharing knowledge to knowledge management system: examining the motivator and the benefits in a Omani organization", Journal of Organizational Knowledge Management, Vol. 2010 No. 1, pp. 928-935.

Alavi, M. and Leidner, D.E. (2001), "Review: knowledge management and knowledge management systems: conceptual foundations and research issues", MIS Quarterly, Vol. 25 No. 1, pp. 107-136.
Knowledge management systems success 
VJIKMS

46,1

Bose, R. (2004), "Knowledge management metrics", Industrial Management \& Data Svstems, Vol. 104 No. 6, pp. 457-468.

Brady, M.K., Cronin, J.J. and Brand, R.R. (2002), "Performance-only measurement of service quality: a replication and extension”, Lournal of Business Research, Vol. 55 No. 1, pp. 17-31.

Cabrera, A. and Cabrera, E.F. (2002), "Knowledge-sharing dilemmas", Organization Studies, Vol. 23 No. 5, pp. 687-710.

Chua, A. and Lam, W. (2005), "Why KM projects fail: a multi-case analysis", Lournal of Knowledge Management, Vol. 9 No. 3, pp. 6-17.

Chua, A.Y., Kaynak, S. and Foo, S.S. (2007), "An analysis of the delayed response to Hurricane Katrina through the lens of knowledge management", Lournal of the American Societv for Information Science and Technology, Vol. 58 No. 3, pp. 391-403.

Comrey, A.L. and Lee, H.B. (1992), A First Course in Factor Analysis, Erlbaum, Hillsdale, NJ.

Damodaran, L. and Olphert, W. (2000), "Barriers and facilitators to the use of knowledge management systems", Behaviour and Information Technology, Vol. 19 No. 6, pp. 405-413.

Davenport, T.H. and Prusak, L. (1998), Working Knowledge: Managing What Your Organization Knows, Harvard Business School Press, Boston, MA.

DeLone, W.H. and McLean, E.R. (1992), "Information systems success: the quest for the dependent variable", Information Svstems Research, Vol. 3 No. 1, pp. 60-95.

DeLone, W.H. and McLean, E.R. (2002), "Information systems success revisited", System Sciences in 2002 HICSS Proceedings of the 35th Annual Hawaii International Conference, Hawaii, pp. 2966-2976.

Delone, W.H. and McLean, E.R. (2003), "The DeLone and McLean model of information systems success: a ten-year update”, Journal of Management Information Systems, Vol. 19 No. 4, pp. 9-30.

Delone, W.H. and Mclean, E.R. (2004), "Measuring e-commerce success: applying the DeLone and McLean information systems success model", International Journal of Electronic Commerce, Vol. 9 No. 1, pp. 31-47.

Ferdinand, A. (2006), Structural Equation Modeling Dalam Penelitian Manajemen (4th Edition), Badan Penerbit Universitas Diponegoro, Semarang, Indonesia.

Fornell, C. and Larcker, D.F. (1981), "Structural equation models with unobservable variables and measurement error: Algebra and statistics", Journal of Marketing Research, Vol. 18 No. 3, pp. 382-388.

Galandere-Zile, I. and Vinogradova, V. (2005), "Where is the border between an information system and a knowledge management system?”, Managing Global Transitions, Vol. 3 No. 2, pp. 179-196.

Gold, A.H., Malhotra, A. and Segars, A.H. (2001), "Knowledge management: an organizational capabilities perspective", Journal of Management Information Systems, Vol. 18 No. 1, pp. 185-214.

Goodman, P.S. and Darr, E.D. (1998), "Computer-aided systems and communities: mechanisms for organizational learning in distributed environments”, MIS Quarterly, Vol. 22 No. 1, pp. 417-440.

Hair, J.F., Black, W.C., Babin, B.J. and Anderson, R.E. and Tatham, R.L. (2006), Multivariate Data Analysis, Pearson Prentice Hall, NJ.

Halawi, L. (2005), KMS Success in Knowledge-based Organizations: An Empirical Validation Utilizing the Delone and McLean is Success Model, NOVA South Eastern University. 
Halawi, L.A., McCarthy, R.V. and Aronson, J.E. (2007), “An empirical investigation of knowledge management systems' success”, Journal of Computer Information Systems, Vol. 48 No. 2, pp. 121-135.

He, W., Fang, Y. and Wei, K.K. (2009), "The role of trust in promoting organizational knowledge seeking using knowledge management systems: an empirical investigation", Lournal of the American Societv for Information Science and Technology, Vol. 60 No. 3, pp. 526-537.

Hickins, M. (1999), “Xerox shares its knowledge”, Management Review, Vol. 16 No. 3, pp. 40-46.

Knowledge management systems success

Huber, G.P. (1991), "Organizational learning: the contributing processes and the literatures", Organization Science, Vol. 2 No. 1, pp. 88-125.

Inkpen, A.C. (1996), "Creating knowledge through collaboration”, California Management Review, Vol. 39 No. 1, pp. 123-140.

Jennex, M. and Olfman, L. (2003), "A knowledge management success model: an extension of DeLone and McLean's IS success model”, Ninth Americas Conference on Information Systems in August, Tampa, p. 330.

Jennex, M.E. (2005), Case Studies in Knowledge Management, IGI Global. Hershev.

Jennex, M. and Olfman, L. (2005), “Assessing knowledge management success”, International Iournal of Knowledge Management, Vol. 1 No. 2, pp. 33-49.

Kahn, B.K., Strong, D.M. and Wang, R.Y. (2002), "Information quality benchmarks: product and service performance", Communications of the ACM, Vol. 45 No. 4, pp. 184-192.

Kettinger, W.J. and Lee, C.C. (2005), "Zones of tolerance: alternative scales for measuring information systems service quality”, MIS Quarterly, Vol. 29 No. 4, pp. 607-623.

King, W.R. and Marks, P.V. Jr. (2008), "Motivating knowledge sharing through a knowledge management system", Omega, Vol. 36 No. 1, pp. 131-146.

KPMG (2000), "Knowledge management research report", available at: www.kpmg.nl/Docs/ Knowledge_Advisory_Services/KPMG\%20KM\%20Research\%20Report\%202000.pdf (accessed 12 July 2013).

Kulkarni, U.R., Ravindran, S. and Freeze, R. (2007), "A knowledge management success model: theoretical development and empirical validation”, Lournal of Management Information Sustems, Vol. 23 No. 3, pp. 309-347.

Kwahk, K.Y. and Oh, S.W. (2009), "Examining the effect of user expectations on system use activity”, ECIS 2008 Proceedings, available at: http://aisel.aisnet.org/ecis2008/9 (accessed 15 September 2013).

Levin, D.Z. and Cross, R. (2004), "The strength of weak ties you can trust: the mediating role of trust in effective knowledge transfer”, Management Science, Vol. 50 No. 11, pp. 1477-1490.

Lucas, R.E. Jr. (1978), “Asset prices in an exchange economy”, Econometrica: Journal of the Econometric Society, Vol. 46 No. 6, pp. 1429-1445.

MacCallum, R.C. and Hong, S. (1997), "Power analysis in covariance structure modeling using GFI and AGFI", Multivariate Behavioral Research, Vol. 32 No. 2, pp. 193-210.

McFadyen, M.A. and Cannella, A.A. (2004), "Social capital and knowledge creation: diminishing returns of the number and strength of exchange relationships", Academv of Management Iournal, Vol. 47 No. 5, pp. 735-746.

McGill, T., Hobbs, V. and Klobas, J. (2003), "User developed applications and information systems success: a test of DeLone and McLean's model”, Information Resources Management Lournal, Vol. 16 No. 1, pp. 24-45. 
VJIKMS

46,1

\section{8}

Malhotra, D. (2004), “Trust and reciprocity decisions: the differing perspectives of trustors and trusted parties", Organizational Behavior and Human Decision Processes, Vol. 94 No. 2, pp. 61-73.1

Masrek, M.N., Karim, N.S.A. and Hussein, R. (2007), "Investigating corporate intranet effectiveness: a conceptual framework", Information Management \& Computer Security, Vol. 15 No. 3, pp. 168-183.

Massey, A.P., Montoya-Weiss, M.M. and O’Driscoll, T.M. (2002), "Knowledge management in pursuit of performance: insights from nortel networks", MIS Quarterly, Vol. 26 No. 3, pp. 269-289.

Nattapol, N., Peter, R. and Laddawan, K. (2010), "An investigation of the determinants of knowledge management systems success in banking industry", World Academy of Science, Engineering and Technology, Vol. 71 No. 1, pp. 588-595.

Pan, S.L., Newell, S., Huang, J. and Galliers, R.D. (2007), "Overcoming knowledge management challenges during ERP implementation: the need to integrate and share different types of knowledge", Lournal of the American Society for Information Science and Technology, Vol. 58 No. 3, pp. 404-419.

Parasuraman, A., Zeithaml, V.A. and Berry, L.L. (1985), "A conceptual model of service quality and its implications for future research”, Journal of Marketing, Vol. 49 No. 4, pp. 41-50.

Ragab, M.A. and Arisha, A. (2013), "Knowledge management and measurement: a critical review", Lournal of Knowledge Management, Vol. 17 No. 6, pp. 873-901.

Ragu-Nathan, B.S., Apigian, C.H., Ragu-Nathan, T.S. and Tu, Q. (2004), "A path analytic study of the effect of top management support for information systems performance", Omega, Vol. 32 No. 6, pp. 459-471.

Razak, D.A. and Abduh, M. (2012), “Customers' attitude towards diminishing partnership home financing in Islamic banking", American Iournal of Apblied Science, Vol. 9 No. 4, pp. 593-599.

Roberts, J. (2000), "From know-how to show-how? Questioning the role of information and communication technologies in knowledge transfer", Technologv Analvsis \& Strategic Management, Vol. 12 No. 4, pp. 429-443.

Schmidt, M. and Hollensen, S. (2006), Marketing Research an International Approach, Prentice Hall, London.

Silver, L. and Berggren, B. (2010), “The close relationship strategy - corporate brand development in banking", Lournal of Brand Management, Vol. 17 No. 4, pp. 289-300.

Thatcher, J.B., Loughry, M.L., Lim, J. and McKnight, D.H. (2007), "Internet anxiety: an empirical study of the effects of personality, beliefs, and social support", Information and Management, Vol. 44 No. 4, pp. 353-363.

Tsai, C.H. and Chen, H.Y. (2007), "Assessing knowledge management system success: an empirical study in Taiwan's high-tech industry", Journal of American Academy of Business, Cambridge, Vol. 10 No. 2, pp. 257-262.

Tsai, W. and Ghoshal, S. (1998), "Social capital and value creation: the role of intra firm networks", Academy of Management Journal, Vol. 41 No. 4, pp. 464-476.

Tseng, S.M. (2008), "Knowledge management system performance measure index", Expert Svstems with Applications, Vol. 34 No. 1, pp. 734-745.

Turban, E., Leidner, D., McLean, E. and Wetherbe, J. (2008), Information Technology for Management, John Wiley \& Sons, New York, NY.

Venkatesh, V. and Bala, H. (2008), "Technology acceptance model 3 and a research agenda on interventions", Decision Sciences, Vol. 39 No. 2, pp. 273-315. 
Vorbeck, J., Heisig, P., Martin, A. and Schütt, P. (2003), "Knowledge management in a global company - IBM global services”, Knowledge Management, Springer, Berlin Heidelberg, pp. 292-304.

Wasko, M.M. and Faraj, S. (2005), "Why should I share? Examining social capital and knowledge contribution in electronic networks of practice”, MIS Quarterly, Vol. 29 No. 1, pp. 35-57.

Wiig, K.M., De Hoog, R. and Van Der Spek, R. (1997), "Supporting knowledge management: a selection of methods and techniques", Expert Sustems with Applications, Vol. 13 No. 1, pp. 15-27.

Wilson, T.D. (2002), "The nonsense of "knowledge management", Information Research, Vol. 8 No. 1, p. 144, available at: http://nformationR.net/ir/8-1/paper144.html

Wu, J.H. and Wang, Y.M. (2006), "Measuring KMS success: a respecification of the DeLone and McLean's model”, Information \& Management, Vol. 43 No. 6, pp. 728-739.

\section{Further reading}

Chatterjee, D., Grewal, R. and Sambamurthy, V. (2002), "Shaping up for e-commerce: institutional enablers of the organizational assimilation of web technologies", MIS Quarterlv, Vol. 26 No. 2, 65-89.

Chong, S.C. (2005), "Implementation of knowledge management among Malaysian ICT companies: a study of success factors and organisational performance”, Unpublished academic dissertation, Multimedia University, Selangor.

Clay, P.F., Dennis, A.R. and Ko, D.G. (2005), "Factors affecting the loyal use of knowledge management systems", Sustem Sciences in 2005 HICSS'05 Proceedings of the 38th Anmual Hawaii International Conference, Hawaii, pp. 251-256.

Gray, P.H. and Durcikova, A. (2005-2006), "The role of knowledge repositories in technical support environments: speed versus learning in user performance", Journal of Management Information Systems, Vol. 22 No. 3, pp. 821-834.

Kankanhalli, A., Tan, B.C. and Wei, K.K. (2005), “Contributing knowledge to electronic knowledge repositories: an empirical investigation”, MIS Quarterly, Vol. 42 No. 1, pp. 113-143.

Kettinger, W.J. and Lee, C.C. (1994), "Perceived service quality and user satisfaction with the information services function”, Decision Sciences, Vol. 25 Nos 5/6, pp. 737-766.

Liang, H., Saraf, N., Hu, Q. and Xue, Y. (2007), “Assimilation of enterprise systems: the effect of institutional pressures and the mediating role of top management”, MIS Quarterly, Vol. 31 No. 1, pp. 59-87.

McFadyen, M.A., Semadeni, M. and Cannella, A.A. Jr. (2009), "Value of strong ties to disconnected others: examining knowledge creation in biomedicine", Organization Science, Vol. 20 No. 3, pp. 552-564.

Maier, R. and Remus, U. (2003), "Implementing process-oriented knowledge management strategies”, Lournal of Knowledge Management, Vol. 7 No. 4, pp. 62-74.

Nelson, K.M. and Cooprider, J.G. (1996), "The contribution of shared knowledge to IS group performance", MIS Quarterlv, Vol. 20 No. 4, pp. 409-432.

Nicolaou, A.I. and McKnight, D.H. (2006), "Perceived information quality in data exchanges: effects on risk, trust, and intention to use", Information Sustems Research, Vol. 17 No. 4, pp. 332-351.

O'Dell, C. and Grayson, C.J. (1998), "If only we knew what we know: identification and transfer of internal best practices", California Management Review, Vol. 40 No. 3, pp. 154-174. 
VJIKMS

46,1

Petter, S., DeLone, W. and McLean, E. (2008), "Measuring information systems success: models, dimensions, measures, and interrelationships", Eurobean Iournal of Information Svstems, Vol. 17 No. 3, pp. 236-263.

Pitt, L.F., Watson, R.T. and Kavan, C.B. (1995), "Service quality: a measure of information systems effectiveness", MIS Quarterlv, Vol. 19 No. 2, pp. 173-187.

Ragowsky, A., Ahituv, N. and Neumann, S. (1996), "Identifying the value and importance of an information system application”, Information \& Management, Vol. 31 No. 2, pp. 89-102.

Sabherwal, R., Jeyaraj, A. and Chowa, C. (2006), "Information system success: individual and organizational determinants", Management Science, Vol. 52 No. 12, pp. 1849-1864.

Suhr, D.D. (2006), Exploratory or Confirmatory Factor Analysis?, SAS Institute, Cary.

Thatcher, J.B., McKnight, D., Baker, E.W., Arsal, R.E. and Roberts, N.H. (2011), "The role of trust in postadoption it exploration: an empirical examination of knowledge management systems", Engineering Management, Vol. 58 No. 1, pp. 56-70.

Wang, S. and Noe, R.A. (2010), "Knowledge sharing: a review and directions for future research", Human Resource Management Review, Vol. 20 No. 2, pp. 115-131.

Wiig, K. (1993), Knowledge Management Foundations, Schema Press, Arlington.

Wu, H., Zubair, M. and Maly, K. (2006), "Harvesting social knowledge from folksonomies", Proceedings of the Seventeenth Conference on Hvpertext and Hvpermedia. ACM, New York, NY, pp. 111-114.

\section{About the authors}

Tat Huei Cham is currently a Doctoral Student and Research Assistant at the Faculty of Accountancy and Management, Universiti Tunku Abdul Rahman (UTAR), Malaysia. He received his master's degree in Management Studies from the University of Hertfordshire (UK), Master of Business Administration from INTI International Laureate University (Malaysia) and Bachelor for Business Administration (Hons) Entrepreneurship from Universiti Tunku Abdul Rahman (Malaysia). His research interests focus on information technology, e-commerce, medical tourism, service industry strategy and operations, consumer behaviour, service marketing and organizational behaviour. Tat Huei Cham is the corresponding author and can be contacted at: jaysoncham@gmail.com

Yet Mee Lim is Associate Professor at the Faculty of Accountancy and Management, UTAR, Malaysia. She holds a PhD from the University of Alabama (USA), master's degree (MBA) from the University of New Orleans (USA) and Bachelor of Science (Business Administration) from the University of Southwestern Louisiana (USA). Her research interests focus on organizational behaviour, knowledge management, user acceptance of technology, e-commerce trend, service industry strategy, human resource management and higher education.

Boon Liat Cheng is a Senior Lecturer at Sunway University Business School (SUBS), Sunway University, Malaysia. His educational background includes a $\mathrm{PhD}$. (Management) from Universiti Tun Abdul Razak, a MSc in Marketing from Robert Gordon University, along with a BA (Hons) in Business Administration from Coventry University. His research interests are in the fields of services marketing, consumer behaviour, entrepreneurship and strategic management.

Teck Heang Lee is a Senior Lecturer at HELP University. His research interests are in the fields of accounting, finance and auditing.

For instructions on how to order reprints of this article, please visit our website:

www.emeraldgrouppublishing.com/licensing/reprints.htm

Or contact us for further details: permissions@emeraldinsight.com 